DOI : https://doi.org/10.24843/JFU.2020.v09.i01.p01

pISSN: 2301-7716; eISSN: 2622-4607

Jurnal Farmasi Udayana, Vol 9, No 1, Tahun 2020, 01-12

\title{
Ligan SV2A sebagai Terapi Epilepsi
}

\author{
Novianae, L., ${ }^{1}$ Sumarno ${ }^{1}$ \\ ${ }^{1}$ Department Clinical Pharmacy, Faculty of Pharmacy, \\ Airlangga University, Surabaya, Indonesia, 60115 \\ E-mail coresponding author: lindaesuradilaga@gmail.com
}

Riwayat artikel: Dikirim: 30/10/2019; Diterima: 10/12/2019, Diterbitkan: 25/06/2020

\begin{abstract}
Epilepsi described a condition in which a person has recurrent seizures due to a chronic, underlying process. Seizure is a transient occurrence of sign or symptoms due to abnormal excessive or synchronous neuronal activity in the brain. Seizure are a result of a shift in the normal balance of excitation and inhibition within the CNS. The ILAE has released a 2017 version of seizure-type classification, basic and expanded version. Seizure classification is an important element in designing the treatment plan, because some epileptic drugs have different activities against various seizure types. Antiepileptic drugs to act primaryli by blocking the initiation or spread of seizures through a variety of mechanism. The newer mechanism of antiepileptic drugs is binding to the glycoprotein SV2A. This paper discuss SV2A ligand Levetiracetam and brivaracetam for the treatment of epilepsy. Discussed include aspect pharmacology, some clinical studies about efficasy, safety, and tolerability, so it can provide information related to the new drug SV2A ligand in determining drug choices for the treatment of epilepsy.
\end{abstract}

Keywords: epilepsy, brivaracetam, levetiracetam, seizure, SV2A ligands

\section{ABSTRAK}

Epilepsi menggambarkan suatu kondisi di mana seseorang memiliki risiko kejang berulang karena proses kronik yang mendasarinya. Seizure (kejang) adalah tanda-tanda atau gejala-gejala sementara yang disebabkan oleh aktifitas neuronal otak yang berlebihan. Kejang terjadi karena terjadi ketidakseimbangan eksitasi dan inhibisi dalam CNS. Pada 2017 ILAE telah merilis klasifikasi terbaru tipe seizure, versi dasar dan diperluas. Klasifikasi kejang penting dalam perencanaan terapi epilepsi, sebab obat-obat antiepilepsi memiliki aktifitas yang berbeda. Obat-obat antiepilesi bekerja melalui berbagai mekanisme yang umumnya dengan memblok inisiasi atau penyebaran kejang. Mekanisme terbaru adalah dengan berikatan pada glikoprotein SV2A, yaitu levetiracetam dan brivaracetam, inilah yang akan kita bahas dalam tulisan ini, terkait aspek farmakologi, beberapa studi klinik tentang efikasi, keamanan, dan tolerabilitasnya. Sehingga dapat memberikan informasi terkait ligan SV2A sebagai pilihan dalam terapi epilepsi.

Kata kunci: epilepsi, brivaracetam, kejang, levetiracetam, ligan SV2A

\section{PENDAHULUAN}

\subsection{Epilepsi}

Epilepsi adalah kondisi neurologik yang ditandai dengan seizure (kejang) berulang yang disebabkan oleh gangguan fungsi elektrikal singkat pada otak. Epilepsi dapat terjadi pada semua usia. Dari data infografik WHO pada 2016-2017, lebih dari 50 juta orang di dunia menderita epilepsi, 80\% penderita tersebut hidup di negara dengan pendapatan rendah sampai sedang dan $75 \%$ penderita tidak mendapatkan pengobatan. ${ }^{1}$ Secara global, diperkirakan 5 juta orang tiap tahun yang didiagnosa menderita epilepsi. Setiap tahun pasien yang didiagnosa epilepsi diperkirakan 49 per 100.000 orang di negara maju, sedangkan di negara dengan pendapatan rendah sampai sedang diperkirakan mencapai 130 per 100.000 orang per tahun. ${ }^{2}$

Seizure (kejang) berasal dari kata Latin sacire ("to take possession"). Kejang adalah tanda-tanda atau gejala-gejala sementara yang disebabkan oleh aktifitas neuronal otak yang berlebihan. Epilepsi menggambarkan suatu kondisi di mana seseorang memiliki risiko kejang berulang karena proses 
DOI : https://doi.org/10.24843/JFU.2020.v09.i01.p01

pISSN: 2301-7716; eISSN: 2622-4607

Jurnal Farmasi Udayana, Vol 9, No 1, Tahun 2020, 01-12

kronik yang mendasarinya. Definisi ini berarti bahwa seseorang dengan seizure tunggal, atau seizure berulang karena keadaan yang dapat diperbaiki atau dihindari tidak langsung dianggap menderita epilepsi (walaupun seizure tunggal terkait dengan gambaran klinis atau elektroensefalografi tertentu yang dapat menegakkan diagnosis epilepsi). Karena ada banyak bentuk dan penyebab epilepsi, maka epilepsi mengacu pada fenomena klinis daripada entitas penyakit tunggal. ${ }^{3}$

\subsection{Mekanisme dasar dan penyebab kejang}

Seizure terjadi karena terjadi ketidakseimbangan eksitasi dan inhibisi dalam CNS. ${ }^{3}$ Proses patologi epilepsi terkait dengan neurotransmiter inhibitori dan eksitatori. Hiperpolarisasi neurotransmiter inhibitori akan membuka kanal $\mathrm{K}$ atau $\mathrm{Cl}$ yang menginduksi pengeluaran ion $\mathrm{K}$ atau masuknya ion $\mathrm{Cl}$. Terbukanya kanal $\mathrm{K}$ atau $\mathrm{Cl}$ juga akan menurunkan resistensi membran yang kemudian menurunkan respon terhadap neurotransmiter eksitatori. Neurotansmiter eksitatori akan mendepolarisasi membran. Neurotransmiter eksitatori akan membuka kanal kation spesifik seperti kanal $\mathrm{Na}$, sehingga menyebabkan ion $\mathrm{Na}$ keluar yang mendepolarisasi membran. Respon eksitatori (depolarisasi) juga dapat terjadi bila sebuah neurotransmiter menutup "kebocoran kanal" potasium untuk mengurangi aliran keluar ion potasium. ${ }^{5}$

Dua asam amino neuroaktif yang utama adalah $\gamma$-aminobutyric acid (GABA) sebagai asam amino inhibitori, dan glutamat sebagai asam amino eksitatori primer. ${ }^{5}$

GABA. Fungsi GABA sebagai neurotransmiter inhibitori primer pada CNS. GABA memberikan efek fisiologis bila berikatan dengan reseptor GABA. Reseptor GABA tersebar pada sebagian besar membran sel neuron CNS dan astrocite, yang menurunkan eksitabilitas neuronal melalui beberapa mekanisme. Karena distribusinya yang luas, reseptor GABA mempengaruhi banyak sirkuit neural dan fungsinya. Ada dua tipe reseptor GABA yaitu reseptor GABA ionotropik (GABA A dan GABA C) yang merupakan protein membran multisubunit yang mengikat GABA dan membuka kanal ion $\mathrm{Cl}$ intrinsik. Reseptor GABA metabotropik (GABA B) merupakan pasangan protein $G$ heterodinamik yang mengaktivasi kanal potasium melalui second messenger. Penurunan inhibisi yang dimediasi oleh GABA (bisa karena faktor eksogen, degenerasi neuron GABAergik, atau perubahan pada tingkat reseptor) merupakan faktor utama yang berhubungan dengan kejang. ${ }^{5}$

Glutamat. Sinap glutamaergik ada pada sepanjang CNS. Ikatan glutamat dengan reseptornya menyebabkan respon eksitatori neuronal yang dilanjutkan dengan aktivasi motor neuron, respon sensori akut termasuk peningkatan sensasi nyeri (hiperalgesia), perubahan sinaptik terkait formasi memori, dan neurotoksisitas serebral dari iskemia otak maupun defisit fungsional dari cedera saraf tulang belakang. ${ }^{5}$

Peningkatan rilis atau penurunan reuptake glutamat pada keadaan patologik dapat memimpin pada siklus umpan balik positif meliputi peningkatan level $\mathrm{Ca}$, kerusakan seluler, dan rilis glutamate lebih lanjut. Secara bersamaan proses ini dapat membawa pada eksitotoksisitas, kematian neuronal yang disebabkan eksitasi seluler yang berlebihan. Eksitotoksisitas merupakan salah satu mekanisme patofisiologis pada banyak penyakit, termasuk sindrom degeneratif, stroke dan trauma, hiperalgesia, dan epilepsi. $^{5}$

Banyak faktor yang mengendalikan eksitabilitas neuronal, banyak mekanisme yang dapat menunda propensitas neuron dalam proses terjadinya bursting. Mekanisme intrinsik pada neuron meliputi perubahan pada konduktan kanal ion, respon karakteristik membran reseptor, bufering sitoplasmik, sistem second-messenger, dan ekpresi protein yang ditentukan oleh perubahan transkripsi, translasi, dan paska translasi gen. mekanisme ekstrinsik pada neuron meliputi perubahan jumlah atau tipe neurotransmiter yang ada di sinap, terjadinya modulasi reseptor oleh ion ekstraseluler dan 
DOI : https://doi.org/10.24843/JFU.2020.v09.i01.p01

pISSN: 2301-7716; eISSN: 2622-4607

Jurnal Farmasi Udayana, Vol 9, No 1, Tahun 2020, 01-12

molekul lainnya, input dari sinap dan nonsinap yang bersifat temporal dan spatial. ${ }^{3}$

Pada prakteknya, sangat berguna untuk mempertimbangkan etiologi seizure berdasarkan usia pasien, karena usia merupakan faktor penentu utama penyebab terjadinya seizure atau epilepsi. Selama periode neonatus, penyebab potensial meliputi ensefalopati iskemik-hipoksik, trauma, infeksi CNS, abnormalitas CNS kongenital, dan gangguan metabolik. Pada anak-anak sampai dengan usia $<12$ tahun, paling sering terjadi adalah kejang demam. Sedangkan pada remaja dan orang dewasa, penyebab kejang umumnya adalah trauma kepala, infeksi, disamping banyak faktor lainnya. ${ }^{3}$

Gangguan metabolik seperti ketidakseimbangan elektrolit, keadaan hipo atau hiperglikemia, gagal ginjal, dan kerusakan hati, gangguan endokrin, gangguan hematologik, dan banyak lagi penyakit sistemik yang dapat menjadi penyebab kejang pada semua usia. Begitu pula dengan obat-obatan dan substansi lainnya yang juga dapat menyebabkan kejang. ${ }^{3}$

\subsection{Klasifikasi seizure}

Menentukan tipe seizure sangat penting untuk memfokuskan diagnosa, memilih terapi yang sesuai, dan dapat memberikan informasi penting terkait prognosis. ${ }^{3}$ ILAE telah merilis klasifikasi terbaru tipe seizure versi 2017, yang merupakan revisi dari klasifikasi yang telah dibuat sejak tahun 1981 (Tabel 1). Prinsip dasarnya adalah bahwa seizure dapat bersifat lokal maupun general. Seizure fokal berasal dari jaringan yang terbatas di salah satu hemisphere otak. Sedangkan seizure general muncul dengan cepat yang melibatkan distribusi jaringan sampai pada kedua hemisphere otak. Seizure dengan onset tidak diketahui dapat berupa motor atau non-motor, penggunaan yang paling penting dari klasifikasi ini adalah untuk seizure tonik-klonik yang belum jelas awalnya. Karena itu dengan adanya informasi selanjutnya maka akan dapat di klasifikasikan ke dalam seizure fokal atau general. ${ }^{4}$

Kejang fokal terjadi dalam tiga tahapan yaitu 1) inisiasi pada level seluler karena adanya peningkatan aktifitas elektrikal, 2) sinkronisasi neuron-neuron sekitarnya, 3) menyebar ke daerah sekitar otak yang berdekatan. ${ }^{5}$ Kejang fokal dimulai dari jaringan saraf pada salah satu hemisfere otak atau terdistribusi lebih luas ke jaringan saraf sekitarnya namun masih dalam satu hemisfere. Kejang fokal dapat berupa perubahan sensasi somatik, keseimbangan tubuh, gangguan penglihatan, fungsi otonomik, fungsi pendengaran. Kejang umum muncul dari beberapa titik di otak yang dengan segera melibatkan jaringan saraf di kedua hemisfere otak. Kejang fokal dapat menyebar meluas ke jaringan saraf di kedua hemisfere otak menyebabkan kejang umum. ${ }^{6}$

Tabel 1. Klasifikasi Seizure

$1 \quad$ Focal onset
a. Aware
Impaired awareness
b. Motor onset
Non motor onset
c. Focal to bilateral tonic-clonic
Generalized onset
a. Motor
$\quad$ Tonic-clonic
Other motor
b. Non motor (absence)
Unknown onset
a. Motor
$\quad$ Tonic-clonic
$\quad$ Other motor
Non motor
b. Unclassified

*klasifikasi terbaru International League Against Epilepsy (ILAE) 2017 (R.S. Fisher, et al: Epilepsia 58: 533, 2017).

\subsection{Obat anti epilepsi}

Obat-obat antiepilepsi memiliki mekanisme kerja yang berbeda, yang artinya memiliki efikasi dan toksisitas yang berbeda secara individual. Untuk itu penting bagi praktisi untuk memahami mekanisme kerja obat antiepilepsi dalam merencanakan terapi bagi pasien yang mengalami kejang. ${ }^{6}$

Mekanisme aksi obat-obat antiepilepsi terutama dengan memblok inisiasi atau penyebaran kejang, terjadi melalui mekanisme 
DOI : https://doi.org/10.24843/JFU.2020.v09.i01.p01

pISSN: 2301-7716; eISSN: 2622-4607

Jurnal Farmasi Udayana, Vol 9, No 1, Tahun 2020, 01-12

yang berbeda yang memodifikasi aktifitas kanal ion atau neurotransmiter dan pada kebanyakan kasus obat-obat antiepilepsi memiliki efek pleiotropik. Mekanisme aksi obat-obat anti epilepsi meliputi penghambatan potensial aksi yang tergantung ion $\mathrm{Na}+$ (fenitoin, carbamazepin, lamotrigine, topiramate, zonisamide, lacosamide, rufinamide). Mekanisme lainnya yaitu menghambat kanal Ca2+ (fenitoin, gabapentin, pregabalin), mereduksi aktifitas glutamat (lamotrigine, topiramate, felbamate), meningkatkan fungsi reseptor GABA (benzodiazepine dan barbiturat), meningkatkan kerja GABA (asam valproat, gabpentin, tiagabine), dan memodulasi rilis vesikel sinap (levetiracetam dan brivaracetam). ${ }^{3}$

Obat anti epilepsi secara umum bertujuan untuk mencegah terjadinya kejang tanpa menyebabkan efek samping yang tidak diinginkan, lebih disukai dengan monoterapi dan aturan pakai yang mudah bagi pasien. Klasifikasi kejang merupakan elemen penting dalam merencanakan terapi. Karena beberapa obat anti epilepsi memiliki aktifitas berbeda sesuai tipe kejang. Bagaimanapun, pilihan obat antiepilepsi sering ditentukan berdasarkan kebutuhan spesifik pasien, terutama berdasarkan efek samping yang dialami pasien. $^{3}$

Karena itu, perkembangan obat-obat anti kejang yang baru dengan mekanisme aksi yang baru menjadi sangat penting bagi praktisi dalam pemberian politerapi baru yang rasional, memberikan pilihan terapi yang lebih dapat ditoleransi oleh pasien yang resisten terhadap obat antiepilepsi. $^{7}$

Obat anti kejang generasi pertama dengan mekanisme aksi modulasi kanal $\mathrm{Na}$ atau potensiasi GABA merupakan induser atau inhibitor poten enzim hepatik, karena itu memiliki interaksi dengan beberapa obat. Obat-obat ini pun memiliki efek samping yang memberikan dampak negatif terhadap kualitas hidup pasien. Karena itu terus dilakukan penelitian dan pengembangan obat-obat baru dengan harapan didapatkan obatobat yang dapat memberikan hasil sembuh dari kejang dengan sedikit efek samping. Perkembangan obat-obat antiepilepsi dimulai dari generasi pertama, dilanjutkan generasi kedua dan sekarang memasuki generasi ketiga seperti pada tabel $2 .^{7}$ Selanjutnya obat antiepilepsi generasi ketiga terbaru yang disetujui FDA pada tahun 2014 adalah Brivaracetam.

Secara luas, obat-obat lama seperti fenitoin, asam valproate, carbamazepine, fenobarbital dan etosuximide secara umum digunakan sebagai terapi piliham pertama untuk kebanyakan kejang, karena secara keseluruhan obat-obat tersebut sama efektifnya dengan obat-obat baru, terlebih lagi karena secara signifikan harganya jauh lebih murah. Kebanyakan obat-obat baru yang diperkenalkan pada decade terakhir ini digunakan sebagai terapi tambahan atau terapi alternative, meskipun begitu beberapa sekarang sudah disetujui sebagai terapi pilihan pertama. Obat-obat antiepilepsi yang tersedia di USA dapat dilihat pada Tabel 3. ${ }^{3}$

Tabel 2. Perkembangan obat-obat antiepilepsi di $\mathrm{USA}^{7}$

\begin{tabular}{llllll}
\hline \multicolumn{2}{c}{ Generasi I } & & Generasi II & Generasi III \\
\hline Awal 1900 & Bromides & 1993 & Felbamate & 2008 & Lacosamide \\
1912 & Phenobarbital & 1993 & Gabapentin & 2008 & Rufinamide \\
1937 & Phenytoin & 1994 & Lamotrigine & 2009 & Vigabatrin \\
1954 & Primidone & 1996 & Topiramate & 2011 & Clobazam \\
1960 & Ethosuximide & 1997 & Tiagabine & 2011 & Ezogabine \\
1968 & Diazepam & 2000 & Levetiracetam & 2012 & Perampanel \\
1974 & Carbamazepine & 2000 & Oxcarbazepine & 2013 & Eslicarbazepine \\
1975 & Clonazepam & 2000 & Zonisamide & & \\
1978 & Valproate & 2004 & Pregabalin & & \\
1981 & Clorazepate & & & & \\
\hline
\end{tabular}


DOI : https://doi.org/10.24843/JFU.2020.v09.i01.p01

pISSN: 2301-7716; eISSN: 2622-4607

Jurnal Farmasi Udayana, Vol 9, No 1, Tahun 2020, 01-12

Table 3 Pemilihan obat-obat anti ${ }^{3}$

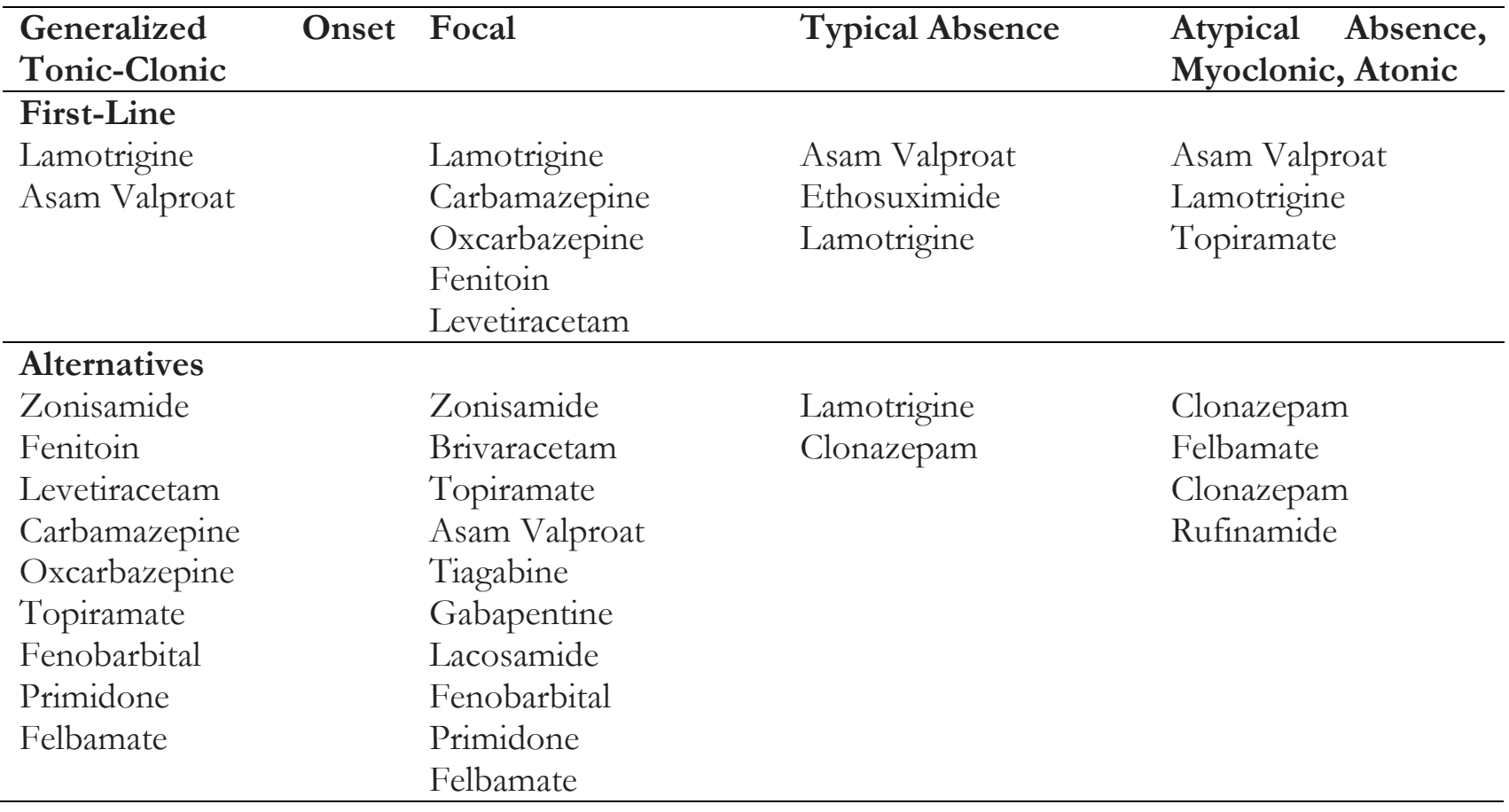

\subsection{Ligan protein synaptic vesicle $2 \mathrm{~A}$ (SV2A)}

SV2A. SV2A baru ditemukan dan diidentifikasikan pada tahun 2003. Awalnya pada tahun 1993, ilmuwan yang melakukan riset levetiracetam mengidentifikasikan tempat ikatan spesifik untuk levetiracetam, selanjutnya disebut sebagai levetiracetam binding site (LBS). LBS khususnya terlokalisasi pada membran plasma sinaptik pada struktur otak, yaitu hipokampus, korteks, dan serebelum. ${ }^{10}$

Glikoprotein synaptic vesicle $2 \mathrm{~V}$ (SV2) merupakan protein yang secara spesifik diidentifikasikan dalam vesikel sinap neron dan granul endokrin. SV2 memiliki 3 isoform yaitu SV2A, SV2B, dan SV2C yang umumnya memiliki stuktur 12-transmembrane-spanning. SV2 merupakan salah satu dari protein vesikel sinaptik yang diidentifikasi. Awalnya SV2 diperkirakan bertindak sebagai vesikuler tranporter karena strukturnya tersebut yang mirip dengan protein transporter, namun sekarang diketahui bahwa SV2 mengatur rilis neurotransmiter eksositotik dan hormon. ${ }^{8}$
Di antara isoform SV2, SV2A sangat banyak di korteks serebral, hipokampus, dan serebelum, pada sinap eksitatori dan inhibitori. Dari ketiga isoform SV2, SV2A adalah yang paling banyak di neuron GABAergik. SV2A adalah protein vesikel sinaptik yang mengatur potensial aksi yang terjadi karena rilis neurotransmitter. SV2A juga memiliki tempat ikatan spesifik terhadap obat anti epilepsi tertentu yang berimplikasi pada terapi epilepsi. ${ }^{8}$

Ligan SV2A. Studi menunjukkan bahwa SV2A memiliki tempat ikatan yang spesifik terhadap derivat racetam (levetiracetam, brivaracetam, seletracetam) ${ }^{8}$

Mekanisme aksi. Mekanisme kerja sebagian besar obat anti epilepsi adalah dengan memodulasi transmisi sinaptik. Levetiracetam dan brivaracetam memiliki mekanisme yang sama, dengan berikatan pada SV2A. ${ }^{9}$

Di dalam neuron presinaptik terdapat sangat banyak vesikel sinaptik yang mengandung neurotransmiter. Vesikel tersebut menuju zona aktif pada membran presinaptik kemudian terikat dengan protein transmembran membentuk kompleks, tahapan ini biasa disebut docking. 
DOI : https://doi.org/10.24843/JFU.2020.v09.i01.p01

pISSN: 2301-7716; eISSN: 2622-4607

Jurnal Farmasi Udayana, Vol 9, No 1, Tahun 2020, 01-12

Tahap selanjutnya adalah priming atau pre-aktifasi vesikel sinaptik. Dengan adanya potensial aksi yang mencapai presinaptik, Ca2+ masuk melalui kanal Ca. Masuknya Ca2+ meningkatkan konsentrasinya di dalam sel presinaptik dan memicu terjadinya perubahan konformasi kompleks protein tadi yang diikuti fusi vesikel dengan membran plasma dan melepaskan neurotransmiter ke celah sinap. Selanjutnya diikuti proses endositosis dan resiklus vesikel sinaptik yang kemudian akan kembali diisi oleh neurotransmiter dan tetap berada dalam intraseluler. ${ }^{9}$

Protein vesikel sinaptik atau SV2 diyakini terlibat dalam tahapan tersebut, tetapi perannya secara spesifik belum jelas. Dari penelitian didapatkan bahwa ikatan levetiracetam dengan protein SV2A mampu mereduksi eksositosis neurotransmiter, yang menurunkan terjadinya transmisi sinaptik. ${ }^{10}$ Kedua ligan tersebut yaitu levetiracetam dan brivaracetam memberikan efek antikonvulsan ketika berikatan dengan SV2A yang memodulasi rilis neurotransmiter. Bagaimanapun, detil bagaimana ikatan tersebut dapat menghasilkan efek antikonvulsan saat ini masih belum diketahui. Juga masih menjadi pertanyaan penting bagaimana molekul tersebut yang mengatur pelepasan semua neurotransmiter baik itu eksitatori maupun inhibitory, dapat menghasilkan inhibisi kejang. ${ }^{12}$

\subsubsection{Profil obat, farmakodinamik dan farmakokinetik}

Levetiracetam. Levetiracetam, awalnya disebut ucb L059, adalah etil S-enantiomer dari analog piracetam. Piracetam adalah obat nootropik yang diindikasikan untuk pengobatan mioklonus kortikal, insufisiensi serebrovaskular, dan gangguan kognitif karena usia. Levetiracetam pada awal risetnya diidentifikasikan sebagai generasi kedua agen nootropik dimaksudkan untuk menggantikan piracetam, namun ternyata gagal menunjukkan aktifitas yang diinginkan. ${ }^{10}$ Pada tes farmakologi selanjutnya ternyata levetiracetam menunjukkan supresi kejang pada model binatang untuk epilepsi. ${ }^{11}$ ? Kemudian dilakukan penelitian lanjutan sampai akhirnya pada tahun 2000 levetiracetam disetujui sebagai salah satu obat dalam terapi epilepsi oleh FDA dan EMA. ${ }^{10}$

Bioavailabilitas levetiracetam lebih dari $95 \%$, waktu untuk mencapai konsentrasi puncak adalah 24-48 jam, ditunda dengan adanya makanan namun konsentrasi maksimum tidak berubah. Rata-rata t1/2 nya adalah 7,6 dan 10,5 jam pada pasien dewasa, anak-anak dan lanjut usia. Levetiracetam dapat diberikan tanpa memperhatikan waktu makan. Levetiracetam mencapai konsentrasi maksimum di cairan serebrospinal dalam waktu 3-7,3 jam, dengan waktu paruh rata-rata 24 jam. Artinya levetiracetam berada dalam kompartemen cairan serebrospinal dua kali lebih lama daripada di dalam darah. Data ini mendukung pengamatan klinik bahwa efikasi antikonvulsan berkepanjangan meskipun konsentrasi serum rendah. ${ }^{11}$

Levetiracetam tidak terikat protein plasma sehingga tidak berpengaruh pada obat-obat yang terikat protein. Tidak dimetabolisme di hati. Levetiracetam tidak menghambat atau menginduksi enzim hepatik yang menyebabkan interaksi secara klinik. Levetiracetam tidak mempengaruhi konsentrasi carbamazepin, clobazam, clonazepam, diazepam, gabapentin, lamotrigine, fenitoin, fenobarbital, primidone, asa, valproat, vigabatrin dan etosuximide. Namun sebaliknya, obat-obat yang menginduksi enzim seperti carbamazepin dapat menurunkan konsentrasi levetiracetam dan meningkatkan klirensnya. Bagaimanapun, karena sedikit sekali interaksi obat lain dengan levetiracetam, maka merupakan pilihan yang sesuai untuk kombinasi terapi dengan antiepilepsi lainnya. Dari penelitian terbaru tidak dikonfirmasikan adanya interaksi yang relevan secara klinik. ${ }^{11}$

Ekskresi primer levetiracetam melalui urine dalam bentuk tidak berubah (64\%), dan penyesuaian dosis perlu dilakukan pada pasien dengan gangguan ginjal. Selain itu $24 \%$ nya dimetabolisme menjadi metabolit inaktif yang dapat ditemukan dalam darah dan urine. ${ }^{11}$

Levetiracetam tersedia dalam bentuk oral (tablet atau larutan) dan intravena. ${ }^{11}$ 
DOI : https://doi.org/10.24843/JFU.2020.v09.i01.p01

pISSN: 2301-7716; eISSN: 2622-4607

Jurnal Farmasi Udayana, Vol 9, No 1, Tahun 2020, 01-12

Brivaracetam. Brivaracetam adalah npropyl analog dari levetiracetam, ligan yang memiliki afinitas tinggi (15-30 kali dari levetiracetam) terhadap SV2A. Merupakan pengembangan dari levetiracetam dengan tujuan untuk mendapatkan obat yang lebih baik secara terapetik. Setelah melalui proses penelitian dan fase-fase klinik, akhirnya pada tahun 2016 disetujui oleh FDA dalam pengobatan epilepsi. ${ }^{9}$

Pada studi dengan dye-loaded vesicles, brivaracetam lebih efektif secara signifikan memperlambat stimulasi pelepasan vesikel dibandingkan levetiracetam. Hal itu menunjukkan perbedaan ikatan antara levetiracetam dan brivaracetam mempengaruhi perbedaan keduanya dalam efikasi farmakologinya. ${ }^{13}$

Hasil yang didapatkan dari studi yang telah dilakukan, mengindikasikan bahwa aktifitas antiepilepsi brivaracetam secara signifikan tidak dipengaruhi mekanisme aksi konvensional seperti obat-obat antiepilesi sebelumnya. Brivaracetam tidak menunjukkan efek langsung pada reseptor AMPA, GABA, glycine, atau kainate, sedikit efek inhibitori pada reseptor N-metil-D-aspartate (NMDA) namun pada konsentrasi supraterapetik. Kontras dibandingkan dengan levetiracetam, yang memiliki mekanisme aksi tidak hanya dengan berikatan pada SV2A, namun juga menghambat reseptor a-amino-3-bidrokdi-5-metil-4isoxazolepropionic acid (AMPA) dan arus high-voltagegated calcium. ${ }^{13}$

Brivaracetam memiliki kelarutan sangat tinggi dalam lipid, dibandingkan dengan benzodiazepin dan fenitoin, juga levetiracetam. Masuk ke dalam otak dengan sangat cepat, melintasi sawar darah otak melalui difusi pasif dan mengikat SV2A sebagai molekul target hanya dalam hitungan menit pada rute pemberian intravena. ${ }^{13}$

Brivaracetam tersedia dalam bentuk sediaan oral tablet salut film dosis 10, 25, 50, 75, dan 100 $\mathrm{mg}$, larutan oral $10 \mathrm{mg} / \mathrm{ml}$, larutan intravena 50 $\mathrm{mg} / 5 \mathrm{ml}^{14}$

Farmakokinetik brivaracetam adalah linier dan dose-dependent, diabsorbsi cepat dan sempurna dari saluran gastrointestinal, makanan mengandung lemak tinggi akan menunda absorpsinya dan memperpanjang waktu untuk mencapai konsentrasi plasma maksimum dari 1 jam menjadi 3 jam. ${ }^{14}$

Meskipun brivaracetam mengalami first-pass metabolisme di hati, namun $90 \%$ komponen yang masuk dalam sirkulasi dalam bentuk tidak berubah, secara luas dimetabolisme di hati menjadi tiga mentabolit inaktif. Jalur metabolik utama adalah hidrolisis yang dimediasi enzim amidase. Eliminasi brivaracetam baik metabolit maupun yang tidak berubah melalui ginjal, dimana obat tidak berubah di dalam urine hanya $8,3 \%$ dari dosis yang diberikan. Brivaracetam aman bagi pasien dengan kerusakan ginjal berat, tapi tetap hati-hati karena bagaimanapun juga akumulasi metabolit memberikan efek toksisitas rendah. Selain itu, pada pasien dengan gangguan fungsi liver berat dianjurkan untuk menurunkan dosis sampai 33\% dengan dosis maksimal $150 \mathrm{mg}$ sehari. Pada populasi penelitian terkait farmakokinetik diidentifikasikan bahwa berat badan dan obat-obat antiepilesi yang memiliki aktifitas menginduksi enzim (zarbamazepin, fenitoin, dan fenobarbital) adalah faktor yang mempengaruhi eliminasi brivaracetam secara signifikan. ${ }^{14}$

Seletracetam. Seletracetam adalah salah satu ligan SV2A yang masih dalam riset pengembangan, diidentifikasikan selama program riset oleh UCB untuk menemukan SV2A ligan yang selektif, berafinitas tinggi dan lebih baik dari levetiracetam. Seletracetam masih dalam tahap penelitian dengan binatang, yang sudah menunjukkan potensial tinggi dalam menekan kejang pada kasus epilepsi yang didapat ataupun epilepsi karena genetik. Sama seperti brivaracetam, seletracetam lebih selektif terhadap SV2A daripada levetiracetam. ${ }^{9}$ Seletracetam dan brivaracetam, keduanya dipilih untuk dikembangkan secara klinik, dimana brivaracetam yang dikembangkan sampai tahapan disetujui sebagai obat epilepsi. ${ }^{13}$

\subsubsection{Indikasi}

Levetiracetam. FDA menyetujui levetiracetam sebagai obat antiepilepsi pada tahun 
DOI : https://doi.org/10.24843/JFU.2020.v09.i01.p01

pISSN: 2301-7716; eISSN: 2622-4607

Jurnal Farmasi Udayana, Vol 9, No 1, Tahun 2020, 01-12

1999 dengan indikasi awal sebagai terapi tambahan untuk pengobatan partial onset seizure pada pasien dewasa dengan epilepsy. Setelah melewati berbagai tahapan studi klinik dan pengembangan, pada tahun 2017 FDA menetapkan levetiracetam sebagai terapi tambahan pada:

- Partial onset seizure pada pasien dengan epilepsy mulai dari usia 1 bulan.

- Myoclonic seizure pada pasien dengan juvenile myoclonic epilepsy mulai dari usia 12 tahun.

- Primary generalized tonic-clonic seizures pada pasien dengan idiopathic generalized epilepsy mulai dari usia 6 tahun. ${ }^{15}$

Brivaracetam. Selanjutnya perkembangan obat epilepsy dari ligan SV2A terus dikembangkan dengan riset-riset dan studi klinik terutama brivaracetam. Pada tahun 2016 FDA menyetujui brivaracetam sebagai terapi tambahan untuk pengobatan partial onset seizure pada pasien dengan epilepsy mulai dari usia 16 tahun. Terbaru pada bulan Mei 2018, FDA menetapkan indikasi baru brivaracetam bukan lagi sebagai terapi tambahan namun dapat sebagai terapi partial onset seizure pada pasien mulai usia 4 tahun. Sediaan intravena hanya diindikasikan sebagai terapi partial onset seizure pada pasien mulai dari usia 16 tahun. ${ }^{16}$

\subsubsection{Efikasi klinik, keamanan tolerabilitas}

Banyak uji coba klinik yang telah dilakukan terutama untuk penggunaan levetiracetam, namun yang dimasukkan dalam daftar seperti dapat dilihat pada Tabel 5 dan 6 adalah uji coba yang dilakukan dengan metode double-blind randomized controlled-trial (RCT).

Penelitian tentang perbandingan penggunaan levetiracetam dengan brivaracetam secara langsung untuk sementara masih belum ada, penelitian yang sudah dilakukan adalah perbandingan masing-masing obat tersebut dengan plasebo ataupun dibandingkan dengan obat antiepilepsi lainnya seperti carbamazepin atau lamotrigin. ${ }^{11}$
Levetiracetam. Secara umum, keamanan penggunaan levetiracetam sebagai terapi tambahan obat antiepilepsi pada pasien dengan epilepsi fokal sangat menjanjikan. Beberapa review mengungkapkan efek samping levetiracetam tidak berbeda secara signifikan dengan plasebo sebagai tambahan pada obat antiepilepsi. Reaksi efek samping biasanya berkurang atau menghilang dengan pengurangan dosis atau penghentian dosis. ${ }^{11}$

Penelitian multicenter di Eropa yang dilakukan oleh Shorvon dkk yang melibatkan 324 pasien pada 61 pusat studi, di dapatkan hasil levetiracetam secara signifikan menurunkan frekuensi kejadian kejang parsial dibandingkan dengan plasebo. Pemberian levetiracetam tidak mempengaruhi konsentrasi plasma atau parameter laboratorium dari obat antiepilepsi lainnya walaupun diberi bersamaan. Juga tidak didapatkan perbedaan yang signifikan terhadap efikasi maupun kejadian efek samping pada pemberian dosis $1000 \mathrm{mg}$ dibandingkan $2000 \mathrm{mg}$, atau di antara plasebo dengan grup levetiracetam. Efek samping yang paling banyak dilaporkan pada penelitian ini adalah asthenia (lemah), sakit kepala, dan penurunan kesadaran (somnolence). ${ }^{17}$

Penelitian lain dilakukan oleh Betts, dkk, suatu studi multicenter, acak, double-blind yang mengevaluasi efikasi dan tolerabilitas dua dosis levetiracetam yaitu $2000 \mathrm{mg}$ dan $4000 \mathrm{mg}$ sehari pada 119 pasien dengan epilepsi refraktori. Didapatkan hasil levetiracetam ditoleransi dengan baik pada dosis $2000 \mathrm{mg}$ dan $4000 \mathrm{mg}$. efek samping yang paling sering terjadi adalah penurunan kesadaran dan kelemahan. Dari hasil penelitian ini pula didapatkan data yang mendukung penelitian preklinik, ${ }^{(6-8)}$ menunjukkan levetiracetam memiliki spektrum luas karena menurunkan frekuensi kejadian kejang parsial, kejang umum primer maupun sekunder. ${ }^{18}$

Di USA dilakukan penelitian pada 294 pasien dengan kejang parsial di 41 tempat studi, dosis levetiracetam 1000-3000 mg per hari dibandingkan dengan plasebo. Metode acak, double-blind, grup pararel. Hasil penelitiannya menunjukkan pemberian kedua grup dosis levetiracetam memberikan penurunan frekuensi 
DOI : https://doi.org/10.24843/JFU.2020.v09.i01.p01

pISSN: 2301-7716; eISSN: 2622-4607

Jurnal Farmasi Udayana, Vol 9, No 1, Tahun 2020, 01-12

kejadian kejang secara bermakna dibandingkan plasebo. Kejadian efek samping yang dilaporkan adalah $88,4 \%$ pada grup plasebo, $88,8 \%$ pada grup levetiracetam dosis rendah dan $89,1 \%$ pada grup levetiracetam dosis tinggi, tidak berbeda secara signifikan. Perawatan terhadap efek samping yang emergensi meliputi kejadian asthenia, dizziness, gejala serupa flu, sakit kepala, infeksi, rinitis dan somnolen lebih sering dilakukan pada grup levetiracetam daripada plasebo. ${ }^{19}$

Studi SKATE ${ }^{\mathrm{TM}}$ dilakukan di 240 tempat dari 16 negara di antara Agustus tahun 2000 sampai dengan Februari 2004 dengan jumlah 1548 pasien yang terlibat. Didapatkan data penurunan frekuensi kejang selama periode penelitian sebesar $51,4 \%$ pada kejang parsial dan 50,2\% pada semua kejang, dan 16,2\% pasien mengalami seizure-free. Penelitian ini menunjukkan bahwa pasien dengan refractory partial onset seizure yang mendapatkan tambahan terapi levetiracetam memberikan tolerabilitas dan efektifitas yang baik. ${ }^{20}$

Percobaan-percobaan penting yang telah dilakukan sebelumnya membawa levetiracetam ditetapkan sebagai monoterapi pada epilepsi fokal. Studi berikut membandingkan levetiracetam dengan carbamazepin controlled-release pada pasien dewasa dengan onset fokal seizure atau bilateral tonic-clonic seizure. Konsep dasar studi tersebut adalah untuk menunjukkan noninferiority bukannya untuk mencari obat mana yang lebih superior. Jadi dimaksudkan untuk melihat bahwa dari kedua obat antiepilepsi tersebut memiliki efektifitas sama. Studi tersebut menunjukkan $73 \%$ pasien yang diterapi dengan levetiracetam dan $72,8 \%$ pasien dengan carbamazepin, bebas kejang pada evaluasi di dosis terakhir. Hasil itu membuktikan bahwa levetiracetam tidak kurang efektif dibanding carbamazepin. Begitu juga dengan proporsi pasien yang mengalami paling sedikit satu kejadian efek samping menunjukkan keamanan yang hampir sama, 79,6\% pada levetiracetam dan 80,8\% pada carbamazepin. ${ }^{21}$

Studi yang dilakukan sejak September 2001 sampai dengan Juni 2005, di 50 pusat penelitian pada 164 pasien dengan idiopathic generalized epilepsies, dilakukan untuk meneliti efikasi dan keamanan levetiracetam. Desain penelitian adalah acak, double-blind, placebo-controlled, parallel group study yang melibatkan pasien dari usia 4-65 tahun. Hasilnya pada evaluasi di minggu ke-2 menunjukkan penurunan $\geq 50 \%$ penurunan frekuensi kejang umum tonik-klonik pada grup levetiracetam adalah $64,6 \%$ pasien, sedangkan grup plasebo $45,2 \%(p=0,018)$. Sedangkan selama periode evaluasi pasien yang bebas kejang tonikklonik general dengan levetiracetam adalah $34,2 \%$ dibandingkan plasebo $10,7 \% \quad(\mathrm{p}<0,001)$. Penelitian ini menunjukkan levetiracetam efektif dan memiliki tolerabilitas baik pada pengobatan pasien dengan idiopathic general epilepsies. ${ }^{22}$

Penelitian berikutnya membandingkan lamotrigine dengan levetiracetam pada pasien dengan fokal dan general epilepsi, suatu studi multicenter, dengan 409 pasien berusia $\geq 12$ tahun yang di baru diagnosa fokal atau general epilepsi. Periode penelitian Maret 2005 - Oktober 2007. Dengan hasil penelitian menunjukkan tidak adanya perbedaan efikasi dan tolerabilitas yang signifikan antara levetiracetam dan lamotrigine pada pasien baru dengan epilepsi fokal atau general. ${ }^{23}$

Brivaracetam. Uji klinik fase 3 multicenter, dari Desember 2010-Desember 2013, pada 760 pasien penderita epilepsi berusia 16-80 tahun, di 127 pusat penelitian pada 27 negara telah dilakukan untuk menguji efikasi dan keamanan/tolerabilitas brivaracetam sebagai terapi tambahan pada epilepsi. Dengan hasil penelitian bahwa terapi tambahan dengan brivaracetam menunjukkan efikasi dalam penurunan partial onset seizure dan ditoleransi dengan baik pada pasien dewasa, tanpa pemberian kombinasi dengan levetiracetam. Diungkapkan pula bahwa efek samping yang paling sering muncul adalah somnolen, dizzines dan fatigue. ${ }^{24}$

Studi tentang brivaracetam postmarketing sebagai terapi epilepsi salah satunya dilakukan oleh Steinig dkk. Merupakan studi multicenter dengan sampel 262 pasien yang mulai di terapi dengan brivaracetam di antara Februari sampai November 2016. Pasien yang terlibat adalah pasien dengan diagnosa epilepsi fokal, idiopatik general, dan simtomatik general. Studi yang 
DOI : https://doi.org/10.24843/JFU.2020.v09.i01.p01

pISSN: 2301-7716; eISSN: 2622-4607

Jurnal Farmasi Udayana, Vol 9, No 1, Tahun 2020, 01-12

dilakukan di Jerman ini menunjukkan bahwa efikasi klinis brivaracetam adalah 40,5\% pada bulan keenam ( $50 \%$ responder rate) dengan 15,3\% pasien bebas kejang. Secara signifikan penggunaan brivaracetam sebagai antikonvulsan postmarketing ditoleransi dengan baik. Efek samping yang sering terjadi adalah somnolen, dizziness, dan efek samping terkait perilaku. ${ }^{25}$

Selain itu, Scubert-Bast dkk melakukan riset multicenter secara retrospective untuk mengevaluasi efikasi, retensi, keamanan dan tolerabilitas brivaracetam pada anak-anak dan remaja ( $\leq 17$ tahun) dengan epilepsi fokal, periode 2016 dan 2017. Pasien yang terlibat 34 orang pasien anak dengan epilepsi fokal pada 4 pusat penelitian epilepsi di Jerman. Pada awal memulai terapi tambahan dengan brivaracetam pasien anak sudah mendapatkan terapi dengan obat antiepilepsi lainnya. Pada hasil studi ini dilaporkan pasien anak yang mengalami penurunan kejadian kejang $\geq 50 \%$ yaitu, 12 pasien ( $\mathrm{n}=12 / 34 ; 35 \%)$ dengan empat pasien (12\%) bebas kejang pada bulan keenam, kemudian tujuh pasien $(21 \%)$ pada bulan kedua belas tanpa ada pasien yang bebas kejang. Perawatan emergensi terhadap efek samping dilaporkan terjadi pada 4 pasien $(12 \%)$, di mana sedasi dan somnolen adalah kondisi yang paling banyak dilaporkan, diikuti efek samping psikotik (depresi, agresi, atau iritabilitas). Dari hasil penelitian ini, Schubart-Bast dkk menyimpulkan bahwa tingkat penurunan kejang dan bebas kejang pada pasien anak dan remaja dengan epilepsi fokal secara potensial dapat dicapai dengan penggunaan antiepilesi brivaracetam. Efek samping yang terjadi sebanding dengan penggunaan antiepilepsi lainnya. ${ }^{26}$

Penelitian terbaru untuk mengevaluasi efektifitas dan tolerabilitas penggunaan jangka panjang brivaracetam pada pasien dengan epilepsi fokal dilakukan oleh Villanueva dkk, periode November 2016 - Juni 2017. Studi dilakukan secara retrospektif dengan 575 pasien. Hasilnya menunjukkan terjadi penurunan frekuensi kejang $36 \%, 39,7 \%$ pasien memberikan respon $\geq 50 \%$ dan $17,5 \%$ pasien bebas kejang setelah terapi selama 12 bulan. Dari total pasien yang mengalami bebas kejang, $37,5 \%$ nya berusia $\geq 65$ tahun. Dari segi tolerabilitas/keamanan, insiden efek samping 39,8\% dan efek samping psikiatrik $14,3 \%$. Efek samping yang paling sering terjadi adalah somnolen, iritabilitas dan dizzines. Kesimpulan dari penelitian ini adalah pada populasi pasien yang resisten obat antiepilepsi, brivaracetam cukup efektif dan dapat ditoleransi dengan baik. Insiden efek samping psikiatrik ditunjukkan lebih rendah dari levetiracetam. ${ }^{27}$

Sebuah studi meta analisis dilakukan oleh Zhang dkk yang membandingkan (perbandingan tidak langsung) penggunaan levetiracetam dengan brivaracetam pada pasien dewasa dengan refractory focal seizures. Studi ini mengungkapkan bahwa 1876 pasien yang diteliti, levetiracetam menunjukkan efikasi sedikit lebih tinggi dan probabilitas dizziness lebih rendah dibandingkan brivaracetam. ${ }^{28}$ Kesimpulan penulis tersebut masih berdasarkan data-data yang terkumpul sampai dengan waktu dilakukannya meta analisis tersebut, di mana penelitian terkait levetiracetam jauh lebih banyak dibandingkan brivaracetam yang lebih baru dirilis. Karena itu, studi terkait penggunaan brivaracetam masih harus terus dilakukan, terutama dengan keamanan penggunaannya khususnya pada pasien anak. Sejauh yang penulis ketahui, belum ada dilakukan penelitian yang membandingkan secara langsung penggunaan levetiracetam vs brivaracetam.

\section{KESIMPULAN}

Epilepsi adalah suatu kondisi di mana seseorang memiliki risiko kejang berulang karena proses kronik yang mendasarinya. Pilihan terapi tergantung tipe kejang yang dialami. Menentukan tipe kejang sangat penting untuk memfokuskan diagnosa, memilih terapi yang sesuai, dan dapat memberikan informasi penting terkait prognosis.

Secara umum obat antiepilepsi bertujuan untuk mencegah terjadinya kejang tanpa menyebabkan efek samping yang tidak diinginkan, lebih disukai dengan monoterapi dan aturan pakai yang mudah bagi pasien.

Obat-obat antiepilepsi memiliki mekanisme aksi yang berbeda-beda, namun umumnya terutama dengan memblok inisiasi atau 
DOI : https://doi.org/10.24843/JFU.2020.v09.i01.p01

pISSN: 2301-7716; eISSN: 2622-4607

Jurnal Farmasi Udayana, Vol 9, No 1, Tahun 2020, 01-12

penyebaran kejang, terjadi melalui mekanisme yang berbeda yang memodifikasi aktifitas kanal ion atau neurotransmiter. Salah satu mekanisme aksi obat antiepilepsi adalah dengan membentuk ikatan protein dengan SV2A, dimana SV2A merupakan protein vesikel sinaptik yang mengatur potensial aksi yang terjadi karena rilis neurotransmitter. Agen yang berikatan dengan SV2A adalah levetiracetam, brivaracetam, dan seletracetam. Yang sudah lama digunakan sebagai obat antiepilepsi adalah levetiracetam, diikuti baru-baru ini oleh brivaracetam, sedangkan seletracetam masih belum dikembangkan.

Sudah banyak uji-uji klinik yang telah dilakukan, studi-studi meta analisis terkait efikasi, keamanan, dan tolerabilitas levetiracetam dan brivaracetam. Dimana studi terkait levetiracetam lebih banyak dilakukan karena sudah lebih dahulu diperkenalkan dibandingkan brivaracetam. Hasil studi-studi tersebut menunjukkan bahwa levetiracetam sebagai memberikan terapi yang efektif dan dapat ditoleransi dengan baik, dengan interaksi obat sangat minim. Karena itu levetiracetam masuk dalam pilihan terapi epilepsi bersama-sama dengan obat antiepilepsi lainnya yang sudah lebih dahulu dipakai. Brivaracetam yang adalah derivatnya juga memiliki efektifitas yang sebanding dengan levetiracetam, namun karena masih baru, perlu dilakukan penelitian berkelanjutan.

\section{DAFTAR PUSTAKA}

1. World Health Organization. Infographics on epilepsy: 2016-2017.2017. available from:

http:/www.who.int/mediacentre/infograph ic/mental-health/epilepsy/en. Accessed September 23, 2019.

2. World Health Organization. Epilepsy. Available from: http:/www.who.int/en/news-room/factsheets/detail/epilepsy. Accessed September 23, 2019.

3. D. H. Lowenstein. Seizures and Epilepsy; in J.L. Jameson, D.L. Kasper, D.L. Longo, A.S. Fauci, S.L. Hauser and J. Loscaldo, Harrison's Principles of Internal Medicine,
Edition 20 ${ }^{\text {th }}$, New York, Mc Graw Hill Education, 2018, pp. 3050-3068.

4. R.S. Fisher, et al, Instruction Manual for the ILAE 2017 Operational Classification of Seizure types, Epilepsy, Vol. 58(4), pp. 533, 2017.

5. D.E. Golan, E.J. Armstrong, A.W. Armstrong, Principles of Pharmacology The Pathophysiologic Basis of Drug Therapy, Edition $4^{\text {th }}$, Philadelphia, Wolter Kluwers health, 2017, pp. 206-223.

6. S.L. Hauser and S.A. Josephson, Harrison's Neurology in Clinical Medicine, Edition $3^{\text {rd }}$, New York, Mc Graw Hill Education, 2013, pp. 238-272.

7. L.A. Rudzinski, et al, New antiepileptic drugs: focus on ezogabin, clobazam, and perampanel, J Investig Med, 64, pp.10871101, 2016

8. K. Tokudome, et al, Synaptic Vesicle Glycoprotein 2A (SV2A) regulates kindling epileptogensis via GABAergic neurotransmission, Scientific Reports, 6, pp.111, 2016.

9. W. Loscher, et al, Synaptiv vesicle Glycoprotein 2A ligands in the treatment of epilepsi and beyond, CNS Drugs, 10, pp.123, 2016.

10. H. Klitgaard dan P, Verdru, Levetiracetam: the first SV2A ligand for the treatment of epilepsy, Expert Opin Drug Discov. 2(11), pp.1537-1547, 2007.

11. B.J. Steinhoff and A.M. Staack, Levetiracetam and brivaracetam: a review of evidence from clinical trials and clinical experience, Ther Adv Neural Disord, Vol.12, pp.1-23, 2019

12. M.D. Wood, M. Gillard, Evidence for a differensial interaction of brivaracetam and levetiracetam with the synaptic vesicle $2 \mathrm{~A}$ protein, Epilepsia, Vol.58(2), pp.255-262, 2017.

13. P. Klein, et al, A review of the pharmacology and clinical efficacy of brivaracetam, Clinical Pharmacology: Advances and Applications, 10, pp:1-22, 2018.

14. J. R. Milovanovic, et al, Evaluation of brivaracetam: a new drug to treat epilepsy, 
DOI : https://doi.org/10.24843/JFU.2020.v09.i01.p01

pISSN: 2301-7716; eISSN: 2622-4607

Jurnal Farmasi Udayana, Vol 9, No 1, Tahun 2020, 01-12

Expert Opinion on Pharmacotherapy, 18:13, pp.1381-1389, 2017.

15. https://www.accessdata.fda.gov/scripts/cd $\mathrm{er} / \mathrm{daf} /$ index.cfm? event $=$ overview.process \&ApplNo=021872, access September 26, 2019.

16. https://www.accessdata.fda.gov/scripts/cd er/daf/index.cfm? event $=$ overview.process \&ApplNo=205838, access September 26, 2019.

17. S.D. Shorvon, et al, Multicentre, doubleblind, randomized, placebo-controlled trial of levetiracetam as add on therapy in patientswith refractory partial seizure, Epilepsia, Volume 41(9), pp.1179-1186, 2000.

18. T. Betts, et al, A multicentre, double-blind, randomized, parallel group study to evaluate the tolerability and efficacy of two oral doses of levetiracetam, $2000 \mathrm{mg}$ daily and $4000 \mathrm{mg}$ daily, without titration in patients with refractory epilepsy, Seizure, Vol.9, pp.80-87, 2000.

19. J.J. Cereghino, et al, Levetiracetam for partial seizures result of a double-blind, randomized clinical trial, Neurology, Vol. 55, pp. 236-242, 2000.

20. B.J. Steinhoff, et al, The SKATE ${ }^{\mathrm{TM}}$ study: an open-label community-based study of levetiracetam as add-on therapy for adults with uncontrolled partial epilepsy, Epilepsy Research, vol.76, pp.6-14, 2007.

21. M.J. Brodie, et al, Comparison of levetiracetam and controlled-release carbamazepin in newly diagnosed epilepsy, Neurology, Vol.68, pp.402-408, 2007.
22. S.F. Berkovic, et al, Placebo-controlled study of levetiracetam in idiopathic generalized epilepsy. Neurology, Vol.69, pp. 1751-1760, 2007.

23. F. Rosenow, et al, The LaLiMo trial: lamotrigine compared with levetiracetam in the initial 26 weeks of monotherapy for focal and generalized epilepsy-an open label, prospective, randomized controlled multicenter study, J. Neurol Neurosurg Psychiatry, Vol.83, pp. 1093-1098, 2012.

24. P. Klein, et al, A randomized, double-blind, placebo-controlled, multicenter, parallelgroup study to evaluate the efficacy and safety of adjunctive brivaracetam in adult patients with uncontrolled partial-onset seizures, Epilepsia, Vol.56, pp.1890-1898, 2015.

25. I. Steinig, et al, Postmarketing experience with brivaracetam in the treatment of epilepsies: a multicenter cohort study from Germany, Epilepsia, Vol.58, pp.1208-1216, 2017.

26. S. Schubart-Bast, et al, Postmarketing experience with brivaracetam in the treatment of focal epilepsy in children and adolescents, Epilepsy \& Behaviour, Vol.89, pp.89-93, 2018.

27. V. Villanueva, et al, BRIVA-LIFE - A multicenter retrospective study of the longterm use of brivaracetam in clinical practice, Acta Neurol Scand, Vol.139, pp.360-368, 2019.

28. L. Zhang, et al, Levetiracetam vc brivaracetam for adults wiyh refractory focal seizures: a meta-analysis and indirect comparison. Seizure, Vol.39, pp.28-33, 2016. 